Jurnal Agroteknologi, Vol. 7 No. 1, Agustus 2016 : 19 - 26

\title{
PEMBERIAN BEBERAPA AMELIORAN TERHADAP PERUBAHAN SIFAT KIMIA TANAH GAMBUT
}

\author{
(Giving Some Ameliorants To Changes Chemical Properties of Peat Soil) \\ ERVINA ARYANTI, YULITA, AULIA RANI ANNISAVA \\ Fakultas Pertanian dan Peternakan UIN Suska Riau \\ Kampus II Raja Ali Haji Jln. Haji Soebrantas Km 15 Pekanbaru \\ Email: hadiderna@yahoo.com
}

\begin{abstract}
The research was conducted in the Faculty of Agriculture and Animal Science State University of Sultan Syarif Kasim Riau. This research aimed to determine best ameliorant which can increase the chemical content of peat soil such as $\mathrm{pH}, N, P, K$ and decrease $C, C / N$. The research used random sampling method, there are: without ameliorant, chicken manure fertilizer, compost of oil palm empty fruits bunches, rice husk ash, and bunch ash. The results showed that give rice husk ash and dolomite can increase some nutrient content of peat. Based on result of the research rice husk ash can increase $P$ from lowest to highest criteria. Giving dolomite increase best $\mathrm{pH}$ value, from sour to neutral.
\end{abstract}

Keywords : Ameliorant, chemical properties, peat soil

\section{PENDAHULUAN}

Lahan gambut merupakan lahan marginal untuk pertanian karena kesuburannya yang rendah, bersifat sangat masam, kapasitas tukar kation yang tinggi, kejenuhan basa yang rendah, kandungan unsur $\mathrm{K}, \mathrm{Ca}$, $\mathrm{Mg}, \mathrm{P}$ dan mikro seperti (Cu, Zn, Mn, B) juga rendah. Keterbatasan lahan bertanah mineral, menyebabkan ekstensifikasi pertanian ke lahan gambut tidak dapat dihindari (Salsi, 2011). Achmad et al. (2011) menambahkan, dewasa ini lahan gambut digunakan untuk berbagai komoditas pertanian, termasuk kelapa sawit, karet, buah-buahan dan sayursayuran, yang memiliki tingkat pengelolaan dan input tinggi, sehingga produktivitas lahan gambut bisa lebih tinggi dari lahan mineral.

Potensi lahan gambut sebagai lahan pertanian di Indonesia cukup luas sekitar 6 juta ha. Pemanfaatannya sebagai lahan pertanian memerlukan perencanaan yang cermat dan teliti, penerapan teknologi yang sesuai, dan pengelolaan yang tepat karena ekosistemnya yang marginal dan fragile. Lahan gambut sangat rentan terhadap kerusakan lahan, yaitu kerusakan fisik (subsiden dan irriversible drying) serta kerusakan kimia (defesiensi hara dan unsur beracun). Pengembangan pertanian dari lahan gambut menghadapi kendala antara lain tingginya asam-asam organik. Pengaruh buruk asam-asam organik yang beracun dapat dikurangi dengan teknologi pengelolaan air dan penambahan bahan-bahan yang banyak mengandung kation polivalen seperti $\mathrm{Fe}, \mathrm{Al}$, $\mathrm{Cu}$, dan Zn (Ratmini, 2012). Krisnohadi (2011) menambahkan, senyawa organik yang bersifat racun dan menghambat pertumbuhan tanaman, dengan demikian perlu adanya penambahan bahan amelioran untuk mengatasi permasalahan kesuburan tanah gambut tersebut. Menurut Salsi (2011) jenis amelioran seperti kapur, abu janjang kelapa sawit, kompos TKKS, abu sekam padi, dan pupuk kotoran ayam dapat meningkatkan unsur hara tanah gambut.

\section{BAHAN DAN METODE}

Penelitian ini dilaksanakan bulan Maret sampai April 2015. Penelitian ini dilakukan di kebun percobaan Fakultas Pertanian dan Perternakan UIN Suska Riau. Analisis kimia tanah gambut dilakukan di Laboratorium Central Plantation Services. Bahan yang digunakan adalah tanah gambut yang diambil dari lahan Fakultas Pertanian dan Perternakan UIN Suska Riau. Amelioran yang digunakan, abu janjang, kompos TKKS, abu sekam, pupuk kotoran ayam, kapur yang dibeli di tokoh pertanian, serta bahan-bahan kimia yang dibutuhkan dalam analisis di laboratorium. Alat yang digunakan cangkul, polibeg, alat tulis, kamera digital, kayu, atap rumbio, saringan $5 \mathrm{~mm}$, meteran, dan alat-alat yang digunakan untuk analisis laboratorium.

\section{Metode Penelitian \\ Penelitian ini merupakan penelitian deskriptif kuantitatif. Pengambilan sampel tanah menggunakan metode pengambilan secara random sampling. Data yang diambil}


diperoleh dari beberapa perlakuan di lapangan kemudian dilakukan analisis untuk mendapatkan data kuantitatif. Analisis sampel tanah yang dilakukan merupakan hasil komposit dari tanah gambut dengan abu janjang kelapa sawit, abu sekam padi, kompos tandan kosong kelapa sawit, pupuk kotoran ayam, kapur seperti di bawah ini:

1. Tanah gambut tanpa perlakuan

2. Tanah gambut + abu janjang kelapa sawit 10 ton/ha (100 g/polibeg)

3. Tanah gambut + kompos tandan kosong 10 ton/ha (100 g/polibeg)

4. Tanah gambut + abu sekam padi 10 ton/ha (100 g/polibeg)

5. Tanah gambut + pupuk kotoran ayam 10 ton/ha (100 g/polibeg)

6. Tanah gambut + kapur 10 ton/ha $(100$ g/polibeg)

Tiap perlakuan terdiri dari 4 ulangan, dengan demikian terdapat 24 polibeg. Masingmasing jenis amelioran tersebut diberikan sesuai dengan perlakuan dan diaduk secara merata. Pengambilan contoh tanah dilakukan setelah diberi perlakukan dan diinkubasi selama satu bulan. Setelah itu dilakukan analisis kandungan hara yang meliputi analisis $\mathrm{pH}, \mathrm{N}, \mathrm{P}, \mathrm{K}, \mathrm{C}, \mathrm{C} / \mathrm{N}$.

\section{Pelaksanaan Penelitian}

\section{Persiapan media}

Media yang dipersiapankan untuk analisis kimia tanah yaitu tanah gambut. Tanah diambil pada kedalaman $0-20 \mathrm{~cm}$, kemudian dibersihkan dari akar dan kotoran yang ada. Tanah gambut adalah tanah yang banyak mengandung air sehingga tanah gambut yang digunakan dalam penelitian dihilangkan kadar airnya terlebih dahulu, dengan cara menghitung kadar airnya agar setara dengan berat keringnnya. Pengukuran berat kering dilakukan dengan cara mengoven tanah gambut sebanyak $100 \mathrm{gr}$ selama 12 jam dengan suhu $105{ }^{\circ} \mathrm{C}$. Selanjutnya tanah diambil sebanyak $10 \mathrm{~kg}$ atau $66,28 \mathrm{~kg}$ setara dengan berat kering mutlak dan memasukkan ke dalam masing-masing polibeg dengan menggunakan perhitungan rumus $=(\%$ kadar air tanah $\mathrm{x}$ berat setara kering mutlak) + berat setara kering mutlak yaitu $(50,87 \% \times 66,28 \mathrm{~kg}$ $+66,28 \mathrm{~kg}=10 \mathrm{~kg}$ ). Tanah yang sudah dimasukkan ke dalam polibeg selanjutnya diberi label sesuai perlakuan.

\section{Tahap inkubasi}

Tanah gambut yang sudah dimasukkan ke dalam polibeg selanjutnya tanah dicampur dan diaduk rata dengan bahan amelioran, yaitu: abu janjang kelapa sawit, kompos tandan kosong kelapa sawit, abu sekam padi, pupuk kotoran ayam, kapur dengan dosis yang sama dan dimasukkan ke dalam polibeg. Tahap selanjutnya dilakukan diinkubasi selama 30 hari dan disiram air setiap hari dengan jumlah air yang diberikan sejumlah kebutuhan untuk mencapai kapasitas lapang.

\section{Pengambilan sampel untuk analisis}

Pengambilan sampel untuk analisis dilakukan setelah tanah diinkubasi selama 30 hari. Setiap polibeg dengan perlakuan yang sama dikompositkan dan diupayakan sehomogen mungkin, selanjutnya tanah diambil sebagian dan dimasukkan ke dalam kantong plastik sebagai sampel yang akan dianalisis.

\section{Analisis data}

Hasil analisis kimia tanah gambut dan amelioran di laboratorium selanjutnya disajikan dalam bentuk tabel dan dibandingkan dengan kriteria penilaian sifat kimia yang telah ditetapkan oleh Balai Penelitian Tanah dan Pengembangan Pertanian (BPTPP), Departemen Pertanian tahun 2005.

\section{HASIL DAN PEMBAHASAN}

\section{Sifat pH, N, P, K, C, C/N Tanah Gambut Sebelum Perlakuan}

Hasil analisis kimia tanah sebelum perlakuan ditampilkan pada Tabel 1 dan dibandingkan dengan kriteria penilaian hasil analisis sifat kimia tanah BPTPP 2005.

Tabel 1. Hasil Analisis Sifat KimiaTanah Gambut Sebelum Diberi Perlakuan

\begin{tabular}{lcc}
\hline Kriteria BPTP 2016 & Sifat Kimia & Tanah Gambut \\
\hline $\mathrm{pH} \mathrm{H} 2 \mathrm{O}$ & 4,64 & Masam \\
N-Total (\%) & 0,27 & Sedang \\
$\mathrm{P} 2 \mathrm{O} 5(\mathrm{ppm})$ & 2,45 & Sangat rendah \\
Kalium (K2O) & 0,23 & Sangat rendah \\
C-organik (\%) & 21,1 & Sangat tinggi \\
Rasio C/N & 78,1 & Sangat tinggi \\
\hline
\end{tabular}

Pada tabel 1. Hasil analisis sifat kimia tanah gambut sebelum diberi perlakuan menunjukkan bahwa nilaip $\mathrm{H}, \mathrm{N}, \mathrm{P}, \mathrm{K}, \mathrm{C}, \mathrm{C} / \mathrm{N}$ tanah sebesar 4,64 (masam), 0,27\% (sedang), 2,45 ppm (sangatrendah), 0,23 mg (sangat rendah), $21,1 \%$ (sangat tinggi), $78,1 \%$ (sangat tinggi).

Rendahnya $\mathrm{pH}$ tanah gambut yaitu 4,64 (masam), berhubungan erat dengan kandungan asam-asam organic dalam jumlah yang tinggi yaitu asam humat dan asam fulvat. Bahan organic yang telah mengalami dekomposisi mempunyai gugus reaktif 
karboksil dan fenol yang bersifat sebagai asam lemah. Diperkirakan $85-95 \%$ sumber kemasaman tanah gambut disebabkan karena kedua gugus karboksil dan fenol tersebut (Nurlida et al., 2011). Kandungan N-total pada tanah gambut tergolong berada pada kondisi sedang $0,27 \%$. Kandungan $\mathrm{N}$ pada tanah gambut berkorelasi dengan tingkat dekomposisi, semakin tinggi dekom posisi maka nilai $\mathrm{N}$ juga akan semakin tinggi atau sebaliknya. Rendahnya tingkat dekomposisi disebabkan terlalu rendahnya $\mathrm{pH}$ tanah gambut sehingga mikroorganisme pengurai tidak dapat hidup dengan baik pada kondisi tanah masam tersebut (Masganti et al., 2014).

Kandungan $\mathrm{P}$ pada tanah gambut tergolong sangat rendah yaitu sebesar 2,45 $\mathrm{ppm}$. Rendahnya kandungan $\mathrm{P}$ pada tanah gambut dikarenakan tanah gambut memiliki kation polivalen yang rendah terutama $\mathrm{Fe}$, sehingga ikatan $\mathrm{P}$ pada tapak reaktif mudah lepas karena gugus reaktif yang terbentuk pada bahan organic tergolong rendah (Salsi, 2011).
Kandungan $\mathrm{K}$ dalam tanah gambut sebesar $0,23 \mathrm{mg}$ dikarenakan tanah gambut memiliki kejenuhan basa dan kadar abu yang juga rendah. Hal ini sangat mempengaruhi kadungan $\mathrm{K}$ dalam tanah gambut (Ratmini, 2012). Kandungan $C$ pada tanah gambut tergolong tinggi yaitu $21,1 \%$ dengan rasio $\mathrm{C} / \mathrm{N}$ sebesar 78,1 (sangat tinggi). Hal ini menunjukkan bahwa perombakan belum sempurna karena proses dekomposisinya sangat rendah sehingga terjadi immobilisasi $\mathrm{N}$. Perombakan dikatakan sempurna apabila nisbah $\mathrm{C} / \mathrm{N}$ lebih kecil dari 20 (Nurhayati, 2008).

\section{Sifat Kimia Amelioran}

Hasil analisis kandungan kimia amelioran, yaitu pupuk kotoran ayam, kompos TTKS, Kapur, Abu sekam padi, AJKS, ditampilkan pada Tabel 2 dan dibandingkan denagan kriteria penilaian hasilan alisis sifat kimia tanah BPTPP 2005.

Tabel 2. Hasil Analisis Sifat pH, N, P, K, C, C/N Amelioran

\begin{tabular}{lllccc}
\hline \multicolumn{1}{c}{ Amelioran Sifat Kimia } & $\begin{array}{c}\text { PK. Ayam } \\
\text { (Kriteria) }\end{array}$ & $\begin{array}{c}\text { KTKKS } \\
\text { (Kriteria) }\end{array}$ & $\begin{array}{c}\text { Kapus } \\
\text { (Kriteria) }\end{array}$ & $\begin{array}{c}\text { As. Padi } \\
\text { (Kriteria) }\end{array}$ & $\begin{array}{c}\text { AJKS } \\
\text { (Kriteria) }\end{array}$ \\
\hline $\mathrm{pHH} 2 \mathrm{O}$ & $6,49(\mathrm{~N})$ & $6,07(\mathrm{~N})$ & $8,54(\mathrm{~A})$ & $6,37(\mathrm{~N})$ & $8,91(\mathrm{~A})$ \\
$\mathrm{N}$-total(\%) & $0,93(\mathrm{ST})$ & $1,44(\mathrm{ST})$ & $0,1(\mathrm{R})$ & $0,75(\mathrm{ST})$ & $0,21(\mathrm{~S})$ \\
$\mathrm{P} 2 \mathrm{O} 5(\mathrm{ppm})$ & $1,63(\mathrm{SR})$ & $0,18(\mathrm{SR})$ & $<0,1(\mathrm{SR})$ & $0,12(\mathrm{SR})$ & $0,13(\mathrm{SR})$ \\
$\mathrm{K} 2 \mathrm{O}(\mathrm{mg} / 100 \mathrm{~g})$ & $0,43(\mathrm{SR})$ & $0,51(\mathrm{SR})$ & $<0,1(\mathrm{SR})$ & $0,28(\mathrm{SR})$ & $0,41(\mathrm{SR})$ \\
$\mathrm{C}-$ Organik $(\%)$ & $22,3(\mathrm{ST})$ & $41,0(\mathrm{ST})$ & $1,56(\mathrm{R})$ & $24,90(\mathrm{ST})$ & $1,76(\mathrm{R})$ \\
Rasio C/N & $24,0(\mathrm{~T})$ & $28,5(\mathrm{ST})$ & $15,6(\mathrm{~S})$ & $33,20(\mathrm{ST})$ & $8,38(\mathrm{R})$ \\
\hline Ket : N: Netral & SR : Sangat Rendah & S: Sedang & T: Tinggi &
\end{tabular}

Pada Tabel 2. Hasil analisis sifat $\mathrm{pH}$, $\mathrm{N}, \mathrm{P}, \mathrm{K}, \mathrm{C}, \mathrm{C} / \mathrm{N}$ ameliorant menunjukkan nilai $\mathrm{pH} \mathrm{H}_{2} \mathrm{O}$ pada pupuk kotoran ayam sebesar 6,49 (netral), kompos TKKS sebesar 6,07 (netral), dan abu sekam padi sebesar 6,37 (netral), sedangakan kapur dan abu janjang kelapa sawit memiliki nilai $\mathrm{pH} \mathrm{H}_{2} \mathrm{O}$ yang cukup tinggi yaitu kapur sebesar 8,54 (alkalis) dan AJKS sebesar 8,91 (alkalis).

Kandungan $\mathrm{N}$ pada beberapa jenis amelioran berada pada kategori sangat tinggi yaitu seperti pada pupuk kotoran ayam sebesar 0,99\%, kompos TKKS1,44\%, dan abu sekam padi $0,75 \%$, sedangkan pada kapur masuk dalam kategori rendah yaitu sebesar $0,1 \%$, dan pada AJKS berada pada kategori sedang yaitu sebesar 0,21\%. Kandungan $P$ pada semua jenis amelioran berada pada kategori sangat rendah seperti pada pupuk kotoran ayam sebesar 1,63 ppm, kompos TTKS sebesar 0,18 ppm, kapur sebesar $<0,10$ ppm, abu sekam padi sebesar $0,12 \mathrm{ppm}$, abu janjang sebesar 0,13 ppm. Kandungan $\mathrm{K}$ pada semua jenis amelioran berada pada kategori sangat rendah seperti pada pupuk kotoran ayam sebesar $0,43 \mathrm{mg}$, kompos TTKS sebesar $0,51 \mathrm{mg}$, kapur sebesar $<0,10 \mathrm{mg}$, abu sekam padi sebesar $0,28 \mathrm{mg}$. AJKS sebesar $0,41 \mathrm{mg}$ (Sulaeman et al., 2005).

Kandungan C pada semua jenis ameliorant berada pada kategori sangat tinggi seperti pada pupuk kotoran ayam sebesar $22,3 \%$, kompos TKKS sebesar $41,0 \%$, abu sekam padi sebesar $24,9 \%$, sedangkan pada kapur sebesar 1,56\% (rendah) dan AJKS sebesar $1,76 \%$ (rendah). Nilai $\mathrm{C} / \mathrm{N}$ pada beberapa ameliorant berada pada kategori sangat tinggi seperti kompos TKKS sebesar $28,5 \%$, AJKS sebesar 33,2\% (sedang), sedangkan kapur sebesar 25,6\% (sedang), pupuk kotoran ayam sebesar $24,0 \%$, dan AJKS sebesar $8,38 \%$ (rendah) (Sulaeman et al., 2005). Tingginya $\mathrm{pH}$ pada kapur dikarenakan kapur banyak mengandung $\mathrm{CaO}$ yang dapat meningkatkan nilaip $\mathrm{H}$, sedangkan AJKS, abu sekam padi pada proses 
pembuatanya mengalami pembakaran pada suhu tinggi sehingga sisa pembakaran menghasilkan basa-basa kation dalam jumlah yang besar seperti $\mathrm{Ca}^{++}, \mathrm{Mg}^{++}, \mathrm{K}^{++}, \mathrm{Na}^{++}$ senyawa-senyawa tersebut banyak menyumbangkan ion $\mathrm{OH}^{-}$(Panjaitan,2007).

Kompos dan pupuk kotoran ayam memiliki pH netral dikarenakan kompos banyak mengandung senyawa organic sederhana dalam bentuk gugus karboksil danp henolik yang mampu mengikat $\mathrm{Al}$ dan $\mathrm{Fe}$ membuka ikatan kompleks sehingga tidak mampu menyumbang kanion $\mathrm{H}^{+}$kedalam tanah yang berarti kondisi ini menurunkan kemasaman (Maryati et al., 2014). Amelioran jenis pupuk kotoran ayam memiliki $\mathrm{pH}$ netral dikarenakan pupuk kotoran ayam berasal dari kotoran ayam yang memiliki kandungan mikroorganisme yang cukup tinggi yang dapat membantu proses dekomposisi dan juga memiliki kadar air yang sangat rendah (Laude dan Tambing, 2010). Kandungan $N$ pada pupuk kotoran ayam, kompos TKKS, dan abu sekam padi, cukup tinggi dikarenakan kandungan $\mathrm{C} / \mathrm{N}$ yang tinggi yaitu $24,0-33,2$. Abu sekam padi memiliki $\mathrm{N}$ yang tinggi dikarenakan telah mengalami pembakaran maka kandungan $\mathrm{N}$ didalamnya akan terlepas dan menghasilkan $\mathrm{N}$ dalam jumlah yang besar. Sedangkan kompos TKKS memiliki kandungan $\mathrm{N}$ yang tinggi karena tandan kosong kelapa sawit memiliki kandungan $\mathrm{C} / \mathrm{N}$ yang tinggi (Mahbub et al., 2011). Kandungan N pada AJKS berada pada kriteria sedang dan kapur pada kriteria rendah. Hal ini disebabkan karena sifatnya yang mudah menguap yaitu $\mathrm{N}$-amonium berubah menjadi $\mathrm{NH} 3$ dan akhirnya menguap (Surya dan Suyono, 2013).

Rendahnya kandungan $P$ dalam semua jenis amelioran dikarenakan unsur $P$ merupakan unsur yang mudah tercuci. Menurut Salsi (2011) unsur $P$ memiliki kation polivalen yang rendah terutama $\mathrm{Fe}$, sehingga ikatan $P$ pada tapak reaktif mudah lepas karena gugus reaktif yang terbentuk pada bahan organik tergolong rendah. Kompos TKKS dan AJKS merupakan amelioran yang berasal dari tandan kosong kelapa sawit. Tandan kosong memiliki kandungan $P$ yang rendah karena $P$ telah diserap oleh biji. Menurut Winarso (2005) pada awalnya tanaman menyerap sebagian besar unsur $P$ dalam bentuk ortofosfat sekunder (H2PO4-), sejumlah kecil diserap dalam bentuk ion otofosfat sekunder $\left(\mathrm{H}_{2} \mathrm{PO}_{4}^{-2}\right)$, pada tanaman muda, kadar $\mathrm{P}$ paling tinggi dijumpai pada pusat pertumbuhan, apabila tanaman sudah memasuk ifase generatif sebagian $P$ diimobilisasi ke biji atau bagian generatif tanaman, besarnya kandungan $\mathrm{P}$ yang diserap tanaman hingga $90 \%$.

Menurut Mahbub et al. (2011) AJKS telah mengalami pembakaran akan melepaskan $\mathrm{P}$ dalam jumlah yang banyak, sehingga kandungan $P$ yang tersedia tergolong rendah. Kandungan $\mathrm{K}$ pada semua jenis amelioran yang digunakan sangat rendah. Kandungan $\mathrm{K}$ pada pada pupuk kotoran ayam, kompos TKKS, kapur, abu sekam padi, AJKS yaitu $0,43,0,51,<0,10,0,28,0,41$. Menurut Purnamayani et al. (2014) salah satu penyebab rendahnya kandungan $\mathrm{K}$ pada semua jenis amelioran dikarenakan sifat $\mathrm{K}$ yang mudah bergerak dan tercuci. Pendapat ini didukung oleh pernyataan Baon dan Sugiyanto (2011) salah satu sifat yang dimiliki unsur $\mathrm{K}$ adalah mudah bergerak dan tercuci, terutama ketika KTK dalam kondisi rendah. Tingginya nilai Corganik pada pupuk kotoran ayam, kompos TKKS, dan abu sekam padi yaitu sebesar 22,3 , $41,0,33,2$, menandakan bahwap roses dekomposisi bahan organik belum dapat diuraikan secara sempurna. Tingginya nisbah $\mathrm{C} / \mathrm{N}$ sangat berhubungan dengan kandungan C-Organik, tingginya kandungan C-Organik menyebabkan tingginya nisbah $\mathrm{C} / \mathrm{N}$.

\section{Perubahan Sifat pH, N, P, K, C, C/N Gambut Setelah Inkubasi}

Hasil analisis kandungan kimia tanah gambut setelah diinkubasi dengan amelioran, yaitu pupuk kotoran ayam, kompos TTKS, Kapur, Abu sekam padi, AJKS, ditampilkan pada Tabel 3 dan dibandingkan denagan kriteria penilaian hasilan alisis sifat kimia tanah BPTPP 2005.

Tabel 3. Hasil Analisis pH, N, P, K, C, C/N Tanah Gambut Pasca Inkubasi dengan Penambahan Pupuk Kotoran Ayam

\begin{tabular}{|c|c|c|c|c|c|c|}
\hline Sifat Kimia & Gambut & $\begin{array}{l}\text { Gambut + } \\
\text { PK Ayam }\end{array}$ & $\begin{array}{c}\text { Gambut+ } \\
\text { Kompos TKKS }\end{array}$ & $\begin{array}{c}\text { Gambut+ } \\
\text { Kapur }\end{array}$ & $\begin{array}{c}\text { Gambut+ Abu } \\
\text { Sekam Padi }\end{array}$ & $\begin{array}{c}\text { Gambut + } \\
\text { AJKS }\end{array}$ \\
\hline $\mathrm{pH} \mathrm{H} 2 \mathrm{O}$ & $4,64(\mathrm{M})$ & $4,62(\mathrm{M})$ & $4,7(\mathrm{M})$ & $6,78(\mathrm{~N})$ & $4,69(\mathrm{~S})$ & $4,72(\mathrm{M})$ \\
\hline N-total (\%) & 0,27 (S) & $0,29(\mathrm{~S})$ & $0,32(\mathrm{~S})$ & $0,28(\mathrm{~S})$ & $0,32(\mathrm{~S})$ & $0,24(\mathrm{~S})$ \\
\hline $\mathrm{P}_{2} \mathrm{O} 5$ (ppm) & 2,45 (SR) & $13,30(T)$ & $14,3(\mathrm{~T})$ & 0,45 (SR) & 68,2 (ST) & $15,00(T)$ \\
\hline $\mathrm{K} 2 \mathrm{O}(\mathrm{mg} / 100 \mathrm{~g})$ & 0,23 (SR) & $0,18(\mathrm{SR})$ & 0,30 (SR) & 0,23 (SR) & $0,30(\mathrm{SR})$ & 0,25 (SR) \\
\hline C-Organik (\%) & 21,1 (ST) & 17,7 (ST) & $23,40(\mathrm{ST})$ & 22,8 (ST) & 22,6 (ST) & $18,00(\mathrm{ST})$ \\
\hline Rasio C/N & 78,1 (ST) & 61,0 (ST) & 73,10 (ST) & 81,4 (ST) & 70,6 (ST) & 75,00 (ST) \\
\hline \multirow[t]{2}{*}{ Ket: $\quad \mathrm{N}$ : } & SR & angat Rendal & & & Tinggi & \\
\hline & ST : & angat Tinggi & $\mathrm{R}: \mathrm{Re}$ & & Masam & \\
\hline
\end{tabular}


Pada tabel 3. Hasil analisis $\mathrm{pH}, \mathrm{N}, \mathrm{P}$, $\mathrm{K}, \mathrm{C}, \mathrm{C} / \mathrm{N}$ tanah gambut pasca inkubasi menunjukkan bahwa pemberian berbagai amelioran tidak meningkatkan kriteria kemasaman tanah kecuali pada pemberian kapur yang meningkat dari 4,67 (Masam) menjadi 6,78 (Netral). Nilai $\mathrm{N}$-total tidak mengalami peningkatan yaitu (Sedang). Pemberian amelioran telah meningkatkan kandungan $\mathrm{P}$ dari rendah menjadi tinggi ( $\mathrm{Pk}$ Ayam, kompos TKKS, AJKS) dan sangat tinggi (abu sekam padi) namun memiliki kriteria tetap pada pemberian kapur. Kandungan K, COrganilk dan nilai Rasio $\mathrm{C} / \mathrm{N}$ tidak mengalimi perubahan kriteria.

Meningkatnya nilai $\mathrm{pH}$ setelah diinkubasi dengan kapur dikarenakan kapur mengandung unsur $\mathrm{Ca}$ dan $\mathrm{Mg}$, dimana kedua unsur ini menggeser kedudukan $\mathrm{H}^{+}$ dipermukaan koloid, sehingga menetralisir keasaman tanah. Selain melalui reaksi hidrolisis dapat melepaskan ion $\mathrm{OH}^{-}$yang berpengaruh terhadap peningkatan $\mathrm{pH}$ tanah (Nurhayati, 2014). Hal ini juga sama dengan pernyataan Maftu'ah et al. (2013) bahwa kapur memberikan pasokan $\mathrm{H}^{-}$ke dalam larutan tanah yang bereaksi dengan $\mathrm{H}+$ menjadi air dan menyebabkan kadar $\mathrm{H}^{+}$berkurang sehingga $\mathrm{pH}$ tanah meningkat. Pemberian kompos TKKS, kapur, abu sekam padi dan AJKS meskipun tidak menaikkan kriteria, namun dapat dilihat bahwa telah terjadi peningkatan $\mathrm{pH}$ gambut. Menurut Purnamayani et al. (2014) kompos TKKS mengandung $\mathrm{Ca}$ yang cukup tinggi sehingga tidak perlu pengapuran lagi, kandungan $\mathrm{Ca}$ yang tinggi dapat meningkatkan $\mathrm{pH}$ tanah gambut. Menurut Maryati et al. (2014) menyatakan bahwa kompos TKKS mampu menurunkan ion $\mathrm{H}+$ hasil dari hidrolisis $\mathrm{AL3}^{+}$ dan $\mathrm{Fe}^{+}$, dekomposisi kompos menyumbangkan senyawa organik sederhana dalam bentuk gugus karboksil dan phenolik yang mampu mengikat $\mathrm{Al}$ dan $\mathrm{Fe}$ membentuk ikatan kompleks (khelat) sehingga tidak mampu menyumbang $\mathrm{H}+$ yang menyebabkan $\mathrm{pH}$ meningkat dengan pemberian kompos. Meningkatnya nilai $\mathrm{pH}$ tanah gambut setelah diinkubasi dengan abu sekam padi dan AJKS dikarenakan nilai dari kedua amelioran yang digunakan dalam percobaan ini bersifat netral yaitu 6,37 (netral) dan 8,91 (alkalis)

$$
\text { Pemberian amelioran tidak }
$$
meningkatkan kriteria kandungan $\mathrm{N}$, namun secara angka terjadi peningkatan. Meningkatnya kandungan $\mathrm{N}$ tanah gambut setelah diberi perlakuan pupuk kotoran ayam dikarenakan bahan organik pupuk kotoran ayam merupakan makanan pokok mikroorganisme tanah yang sebagian terdapat mikroorganisme pengikat N (Tufaila, 2014). Meningkatnya kandungan $\mathrm{N}$ dalam tanah gambut pada pemberian kompos TKKS disebabkan karena kompos yang diberikan ke tanah mengalami dekomposisi menghasilkan hara makro dan mikro, dimana unsur yang dominan salah satunya adalah $\mathrm{N}$ (Ermadani, 2010). Kenaikan kandungan $N$ juga dipengaruhi oleh $\mathrm{pH}$, ion $\mathrm{Fe}$, dan $\mathrm{Al}$, dan tingkat dekomposisi bahan organik. $\mathrm{pH}$ tanah yang diinkubasi dengan kapur mengalami peningkatan sehingga meningkatkan kandungan $\mathrm{N}$ pada tanah gambut (Harjanji, 2009). Peningkatan nilai $\mathrm{pH}$ menyebabkan meningkatnya proses dekomposisi bahan organik yang bayak menghasilkan haa mikro dan makro, dimana unsur yang dominan salah satunya adalah $\mathrm{N}$. Selain itu meningkatnya kandungan $\mathrm{N}$ tanah gambut setelah diinkubasi dikarenakan suplai langsung dari abu sekam padi yang memiliki kandungan $\mathrm{N}$ cukup tinggi yaitu $0,75 \%$ (Ermadani, 2010). Penurunan kandungan $\mathrm{N}$ pada pemberian AJKS menurut Salsi (2011) dikarenakan peningkatan pH gambut karena pemberian abu janjang kelapa sawit. Kondisi pH yang meningkat menyebabkan $\mathrm{N}$-amonium dapat berubah menjadi $\mathrm{NH}_{3}$ dan menguap.

Pemberian amelioran meningkatkan kandungan $\mathrm{P}$, kecuali kapur. Peningkatan kandungan $P$ setelah diinkubasi dengan pupuk kotoran ayam dan kompos TKKS, abu sekam padi dan AJKS dikarenakan amelioran tersebut dapat menurunkan fiksasi $P$ oleh kation asam didalam tanah gambut, sehingga menurut Surya dan Suyono (2013) menyebabkan ketersediaan $\mathrm{P}$ dalam tanah meningkat. Selain itu menurut Ermadai et al. (2011) peningkatan $P$ juga dikarenakan pembentukan senyawa kompleks Al oleh senyawa organik hasil dekomposisi sehingga menurunkan kandungan Al-dd dan mengurangi adsorpsi $\mathrm{P}$ oleh Al sehingga $P$ meningkat. Menurut Salsi (2011) unsur $P$ memiliki kation polivalen yang rendah terutama $\mathrm{Fe}$, sehingga ikatan $\mathrm{P}$ pada tapak reaktif mudah lepas karena gugus reaktif yang terbentuk pada bahan organik tergolong rendah (William dan Koesrini, 2006). Pada pemberian abu sekam padi kenaikan kandungan $\mathrm{P}$ dikarenakan abu sekam padi kaya akan sumber silikat yang dapat melepaskan fosfor terjerap dan mencegah terjadinya fiksasi $P$. Hal ini karena silikat termasuk salah satu anion penentu potensial yang dapat berkompetisi menduduki kompleks jerapan. Dengan demikian sifat kompetisi ini dapat dimanfaatkan untuk meningkatkan ketersedian fosfor (Prijono dan llyas, 2000). Selain itu Salsi (2008), menyatakan bahwa kenaikan $\mathrm{pH}$ juga disebabkan tingginya nilai 
$\mathrm{pH}$ pada amelioran (abu janjang) dapat meningkatkan nilai $\mathrm{pH}$ tanah gambut, kenaikan $\mathrm{pH}$ ini sangat mempengaruhi kenaikkan kandungan $\mathrm{K}$ dan $\mathrm{P}$, semakin tinggi nilai $\mathrm{pH}$ proses dekomposisi oleh organisme juga semakin meningkat, sehingga dapat meningkatkan unsur hara dalam tanah, termasuk unsur $\mathrm{K}$ dan $\mathrm{P}$.

Pemberian amelioran tidak meningkatkan kriterian kandungan $\mathrm{K}$ pada tanah gambut, namun mengalami kenaikan angka. Pupuk kotoran ayam menurunkan kandungan $\mathrm{K}$, sedangkan kapur tidak meningkatkan kandungan $\mathrm{K}$ dalam tanah gambut. Pemberian kompos TKKS meningkatkan kandungan $\mathrm{K}$ tanah gambut yang berasal dari suplai langsung oleh kompos TKKS. Pemberian abu sekam padi meningkatkan kandungan $\mathrm{K}$ tanah gambut. Menurut Kusuma et al. (2013) bahwa penambahan abu sekam padi dapat meningkatkan kadar $\mathrm{P}$ dan $\mathrm{K}$ tanah, dikarenakan abu sekam padi dalam pembuatannya melalui pembakaran sehingga banyak mengandung $\mathrm{SiO} 2, \mathrm{P}$, dan $\mathrm{K}$. Kenaikkan kandungan $\mathrm{K}$ pada pemberian AJKS menurut Imaduddin et al. (2008), senyawa kalium dalam abu janjang kelapa sawit dalam bentuk senyawa karbonat yang memiliki konsentrasi ion karbonat yang sangat tinggi yang sangat dipengaruhi oleh pemanasan, semangkin tinggi pemanasan akan semakin tinggi konsentrasi ion karbonatnya $\left(\mathrm{K}_{2} \mathrm{CO}_{3}\right)$ yang berarti semakin tinggi juga kandungan kaliumnya.

Pemberian pupuk kotoran ayam dan AJKS menurunkan kandungan C-organik tanah gambut, namun masih dalam katagori yang sama yaitu sangat tinggi. Pada pemberian pupuk kotoran ayam menurunkan kandungan C-organik sebesar 4,0\%, sedangkan pemberian AJKS sebesar 3,1\%. Penurunan nilai C-organik berbanding lurus dengan penurunan rasio $\mathrm{C} / \mathrm{N}$. Pemberian kapur meningkatkan kandungan $\mathrm{C}$-organik dan $\mathrm{C} / \mathrm{N}$. Kandungan C-organik setelah diinkubasi dengan kapur mengalami peningkatan $1,7 \%$, sedangkan ratio $\mathrm{C} / \mathrm{N}$ mengalami kenaikan sebesar 3,3\%. Meningkatnya kandungan Corganik menunjukkan bahwa perombakan belum sempurna karena proses dekomposisinya sangat rendah sehingga terjadi immobilisasi $\mathrm{N}$ yang meningkatkan kandungan C-organik (Nurhayati, 2008). Pemberian abu sekam padi meningkatkan nilai C dan menurunkan N/C tanah gambut. Nilai C setelah diinkubasi mengalami kenaikan sebesar 1,5\%. Kenaikan kandungan C dikarenakan suplai langsung dari abu sekam padi yang digunakan yang mengandung $\mathrm{C}$ yang cukup tinggi yaitu sebesar 24,9\%. Pemberian abu sekam padi menurunkan nilai $\mathrm{C} / \mathrm{N}$ tanah gambut. Nilai awal $\mathrm{C} / \mathrm{N}$ sebelum diinkubasi $78,5 \%$ menjadi 70,6\%. Menurunnya nilai $\mathrm{C} / \mathrm{N}$ menandakan bahwa adanya peningkatan terhadap proses dekomposisi tanah gambut yang yang ditandai dengan meningkatnya kandungan unsur hara seperti $\mathrm{pH}, \mathrm{N}, \mathrm{P}, \mathrm{K}$, dan $\mathrm{C}$ tanah gambut setelah diinkubasi (Subatra, 2013). Menurut Riwandi (2002) ratio $\mathrm{C} / \mathrm{N}$ akan cenderung menurun ketika bahan organik meningkat yang terjadi di fase permulaan dekomposisis bahan organik yang terjadi jika dekomposisi senyawa $\mathrm{N}$ melebihi dekomposisi senyawa $\mathrm{C}$.

\section{KESIMPULAN DAN SARAN}

\section{Kesimpulan}

Berdasarkan hasil penelitian ini dapat ditarik kesimpulan bahwa pemberian amelioran pupuk kotoran ayam, kompos TKKS, abu sekam padi dan AJKS tidak merubah kriterian $\mathrm{pH}$ kecuali pada pemberian kapur. Pemberian amelioran juga tidak mengingkatkan kriteria kandungan $\mathrm{N}$ dan $\mathrm{K}$, namun hasil analisis yang diperoleh menunjukkan peningkatan. Penambahan abu sekam padi dapat meningkatkan kandungan $\mathrm{P}$ tanah gambut dengan menaikkan dari kriteria sangat rendah menjadi kriteria sangat tinggi, namun tidak untuk yang lainnya. Kandungan $\mathrm{C}$ dan rasio $\mathrm{C} / \mathrm{N}$ tidak mengalami perubahan kriteria namun hasil analisis yang diperoleh menunjukkan penurunan.

\section{DAFTAR PUSTAKA}

Achmad, A., F. Manalu dan I.R. Handayani. 2011. Pengelolaan Lahan Gambut Berkelanjutan. Balai Penelitian Tanah. Bogor. 103 hal.

Baon, J.B. dan Sugiyanto. 2011. Sifat kimia tanah akibat abu asal tanaman pengganti pupuk kalium dan nilai konversinya. Jurnal Pelita Perkebunan, 27(2) : 98-108.

Ermadani, A. Muzar dan I. Ahmad. 2011. Pengaruh residu kompos tandan kosong buah kelapa sawit terhadap beberapa sifat kimia ultisol dan hasil kedelai. Jurnal Penelitian Universitas Jambi Seri Sains, 13(2): 11-18.

Harjanti, R.S. 2009. Pengujian efektifitas bahan pembenah tanah dolomit untuk kemasaman tanah. Skripsi. Institut Pertanian Bogor. 
Imaduddin, M., Yoeswono, W. Karna, dan T. Iqmal. 2008. Ekstraksi kaliaum dari abu tandan kosong sawit sebagai katalis pada reaksi transesterifikasi minyak sawit. Bulletin of Chemical Engineering dan Catalysis, 3(3): 14-20.

Krisnohadi, A. 2011. Anaisis pengembangan lahan gambut untuk tanaman kelapa sawit Kabupaten Kubu Raya. Jurnal Teknik Perkebunan, 1(1): 1-7.

Kusuma, A.H., I. Munifatul dan E. Saptiningsih. 2013. Pengaruh penambahan arang dan abu sekam dengan proporsi yang berbeda terhadap permeabilitas dan porositas tanah liat serta pertumbuhan kacang hijau (Vigna radiata L.). Buletin Anatomi dan Fisiologi, 21(1): 1-9.

Laude, S. dan Y. Tambing. 2010. Pertumbuhan dan hasil bawang daun (Allium fistulosum L.) pada berbagai dosis pupuk kotoran. Jurnal Agroland, 17(2): 144-148.

Maftu'ah, E., A. Mas, A. Syukur dan B.H. Purwanto. 2013. Evektivitas amelioran pada lahan gambut terdegredasi untuk meningkatkan pertumbuhan danserapan NPK tanaman jagung manis (Zea mays L.). Jurnal Agron Indonesia, 41(1): 1623.

Mahbub, I, A., A. Muzar dan Ermadani. 2011. Pengaruh residu kompos tandan kosong buah kelapa sawit terhadap beberapa sifat kimia ultisol dan hasil kedelai. Jurnal Penelitian Universitas Jambi Seri Sains, 13(2): $11-18$.

Maryati, Nelvia dan E. Anom. 2014. Perubahan kimia tanah sawah saat serapan hara maksimum oleh padi (Oryza sativa L.) setelah aplikasi campuran kompos tandan kosong kelapa sawit (TKKS) dengan abu boiler. Jurnal Agrotek, 1(1): 1-14.

Masganti, I.G.M. Subiksa, Nurhayati dan S. Winda. 2014. Respon tanaman tumpang sari (kelapa sawit dan nenas) terhadap amelioran dan pemupukan di lahan gambut terdegradasi. Balai Penelitian Tanah. Bogor. 117-132.

Nurhayati, Razali dan Zuraidah. 2014. Peran berbagai jenis bahan pembenah tanah terhadap status hara $P$ dan perkembangan akar kedelai pada tanah gambut asal Sumatera Utara. Jurnal Floratek, 1(9): 29-38.

Nurhayati. 2008. Tanggapan tanaman kedelai di lahan gambut terhadap pemberian beberapa jenis bahan perbaikan tanah. Tesis. Universitas Sumatera Utara.

Prijono, S. dan S. Iyas. 2000. Analisis pemberian limba pertanian abu sekam sebagai sumber silikat pada andisol dan oxisol terhadap pelepasan fosfor terjerap dengan teknik perunut. Skripsi. Universitas Brawijaya.

Purnamayani, R., H. Purnama dan Busyra. 2014. Kombinasi kompos tanadan kososng kelapa sawit dan pupuk kandanag sebagai subtitusi pupuk kaliaum terhadap produksi tanaman gambas (Luffa acutangula) di Kabupaten Marangin. Prosiding Seminar Nasional Lahan Suboptimal

Ratmini, S. 2012. Karakteristik dan pengelolaan lahan gambut untuk pengembangan pertanian. Jurnal Lahan Suboptimal, 1(2): 197-206.

Riwandi. 2002. Sifat kimia gambut dan derivat asam fenolat: komposisi unsur VS spectra UV- VIS ekstrak gambut dengan natrium - pirofosfat. Jurnal IImu Pertanian Indonesia, 4(1): 35-41.

Salsi, I. 2011. Karakterisasi gambut dengan berbagai bahan amelioran dan pengaruhnya terhadap sifat fisik dan kimia guna mendukung produktivitas lahan gambut. Jurnal Agrovigor, 1(4): 42-50.

Subatra, K. 2013. Pengaruh sisa amelioran, pupuk $\mathrm{N}$ dan $\mathrm{P}$ terhadap ketersediaan $\mathrm{N}$, pertumbuhan dan hasil tanaman padi di musim tanam kedua pada tanah gambut. Jurnal Lahan Suboptimal, 2(2): 159-169.

Sulaiman., Suparto dan Eviati. 2005. Analisis Kimia Tanah, Tanaman, Air, Pupuk. Balai Penelitian Tanah. Bogor. 15 hal.

Surya, R. E. dan Suyono. 2013. Pengaruh pengomposan terhadap rasio $\mathrm{C} / \mathrm{N}$ kotoran ayam dan kadar hara NPK tersedia serta kapasitas tukar kation tanah. UNESA Journal of Chemistry, 2(1): 137-144.

Tufaila, M. 2014. Aplikasi pupuk kotoran ayam untuk meningkatkan hasil tanaman mentimun (Cucumis sativus L.) di tanah masam. Jurnal Agroteknos, 2(4): 119126.

Winarso, S. 2005. Kesuburan Tanah: Dasar Kesehatan dan Kualitas Tanah. Gava Medis. Yogyakarta. 269 hal. 
Pemberian Beberapa Amelioran Terhadap Perubahan Sifat Kimia (Ervina Aryanti, et al.) 


\section{$\mathbf{J}$

PEMBERIAN KOMPOS TKKS DAN COCOPEAT PADA TANAH SUBSOIL ULTISOL TERHADAP PERTUMBUHAN BIBIT KELAPA SAWIT (Elaeis guineensis Jacq.) DI PRE NURSERY

Composting EFB And Cocopeat On Subsoil Ultisol To The Growth Of Palm Oil Seedlingsin Pre Nursery

Siziko Andri, Nelvia, Sukemi Indra Saputra

PENGARUH INOKULASI CAMPURAN ISOLAT BAKTERI PELARUT FOSFAT INDIGENUS RIAU TERHADAP PERTUMBUHAN DAN PRODUKSI TANAMAN KEDELAI (Glycine max L. Merr)

Effect of Riau Indigenus Phosphate Solubilizing Bacteria Isolate Mixture Inoculation on Soybean Growth and Yield

Lufita Nur Alfiah, Delita Zul, Nelvia

PROPAGASI IN VITRO ANGGREK (Dendrobium phalaenopsis Fitzg) TERHADAP PEMBERIAN HORMON IBA DAN KINETIN

In Vitro Propagation of Orchid (Dendrobium phalaenopsis Fitzg) on The Addition Iba and Kinetion Hormones

Imam Mahadi

PEMBERIAN BEBERAPA AMELIORAN TERHADAP PERUBAHAN SIFAT KIMIA TANAH GAMBUT

Giving Some Ameliorants To Changes Chemical Properties of Peat Soil

Ervina Aryanti, Yulita, Aulia Rani Annisava

ANALISIS PEMASARAN PADI SAWAH DI KECAMATAN RAMBAH SAMO KABUPATEN ROKAN HULU

Marketing Analysis Of Paddy Field In The Rambah Samo District Rokan Hulu Regency

Darus

KEANEKARAGAMAN SERANGGA PADA TUMPANGSARI TANAMAN PANGAN SEBAGAI TANAMAN SELA DI PERTANAMAN KELAPA SAWIT BELUM MENGHASILKAN Insect Diversity on Intercropping System in Young Palm Oil

Lutfi Arifin, Mokhammad Irfan, Indah Permanasari, Auli Rani Annisava, dan A. Taufiq Arminudin ....... 